\title{
The Important Role of STAT3 in Chronic Lymphocytic Leukaemia Biology
}

\author{
Důležitá role STAT3 v biologii chronické lymfocytární leukemie
}

\author{
Boudny M., Trbusek M. \\ Department of Internal Medicine, Hematology and Oncology, Faculty of Medicine, Masaryk University and University Hospital Brno
}

\begin{abstract}
Summary
Background: Signal transducer and activator of transcription (STAT) proteins are cytoplasmic transcription factors that transmit the signal of cytokines, hormones and growth factors. STAT proteins control fundamental cellular processes including survival, proliferation and differentiation. Inappropriate activation of STATs might contribute to cellular transformation and leukaemogenesis. About $70 \%$ of all solid and haematological tumours exhibit aberrant STAT3 expression and/or activation, highlighting its essential role in tumourigenesis. Aberrant STAT3 activation has been found in several solid tumours and haematologic malignancies. Importantly, constitutive activation of STAT proteins has been found in several leukaemias including acute myeloid leukaemia, acute promyelocytic leukaemia, acute lymphoblastic leukaemia, chronic myeloid leukaemia and chronic lymphocytic leukaemia (CLL). Constitutively activated STAT3 plays an important role in CLL biology. CLL cells harbour constitutive phosphorylation on S727 and acetylation on K685 and transient phosphorylation on Y705 residues. Moreover, STAT3 messenger RNA expression is significantly higher in CLL cells compared to healthy B-lymphocytes. Interestingly, STAT3 inhibition was disclosed as an important by-product of ibrutinib treatment in CLL patients. Purpose: The purpose of this review is to describe the consequences of STAT3 dysregulation in CLL cells. Here, we discuss aberrantly modified processes by STAT3 activation in CLL cells such as proliferation, apoptosis, B cell receptor signalling, cytokine secretion, immune checkpoint regulation, microRNA regulation, free fatty acid metabolism and electron transport chain in the mitochondria.
\end{abstract}

\section{Key words}

STAT3 - STAT - chronic lymphocytic leukaemia - therapy - microenvironment - ibrutinib - constitutive activation - leukaemia

\section{Souhrn}

Východiska: Proteiny STAT (signal transducer and activator of transcription) jsou cytoplazmatické transkripční faktory, které přenášejí signál cytokinů, hormonů a růstových faktorů. Proteiny STAT kontrolují základní buněčné procesy vč. přežití, proliferace a diferenciace. Nadměrná aktivace proteinů STAT může přispět k transformaci buněk a vzniku leukemie. Okolo $70 \%$ všech solidních a hematologických nádorů vykazuje aberantní expresi a/nebo aktivaci STAT3, což dokumentuje zásadní roli STAT3 v tumorigenezi. Aberantní aktivace STAT3 byla popsána u několika solidních nádorů a hematologických malignit. Důležité je, že konstitutivní aktivace proteinů STAT byla detekována u několika typů leukemie vč. akutní myeloidní leukemie, akutní promyelocytární leukemie, akutní lymfoblastické leukemie, chronické myeloidní leukemie a chronické lymfocytární leukemie (CLL). Konstitutivně aktivovaný STAT3 hraje důležitou roli v biologii CLL. Buňky CLL jsou konstitutivně fosforylované na S727 a acetylované na K685, navíc může dojít i k fosforylaci na Y705. Exprese mediátorové RNA STAT3 je výrazně vyšší v buňkách CLL ve srovnání se zdravými B lymfocyty. Zajímavé je, že inhibice STAT3 byla popsána jako důležitý vedlejší produkt léčby ibrutinibem u pacientů s CLL. Cíl:Účelem tohoto přehledu je popsat důsledky deregulace STAT3 u buněk CLL. V práci jsou popsány procesy ovlivněné nadměrnou aktivací STAT3 jako proliferace, apoptóza, signalizace $\mathrm{BCR}$ (B cell receptor), sekrece cytokinů, regulace kontrolních bodů imunitního systému, regulace mikroRNA, metabolizmus mastných kyselin a elektronový transportní řetězec v mitochondriích.

\section{Klíčová slova}

STAT3 - STAT - chronická lymfocytární leukemie - terapie - mikroprostředí - ibrutinib - konstitutivní aktivace - leukemie
The work was supported by Project FNBr 65269705 - Conceptual Development of Research Organisation and Project MU$\mathrm{NI} / \mathrm{A} / 1105 / 2018$

Práce byla podpořena projektem FNBr 65269705 - koncepční rozvoj výzkumné organizace a projektem MUNI/A/1105/2018.

The authors declare they have no potential conflicts of interest concerning drugs, products, or services used in the study.

Autoři deklarují, že $v$ souvislosti s predmětem studie nemají žádné komerční zájmy.

The Editorial Board declares that the manuscript met the ICMJE recommendation for biomedical papers.

Redakční rada potvrzuje, že rukopis práce splnil ICMJE kritéria pro publikace zasílané do biomedicínských časopisů.

\section{$\Xi^{\circ}$}

Miroslav Boudny, PhD

Department of Internal Medicine, Hematology and Oncology

Faculty of Medicine

Masaryk University

University Hospital Brno

Jihlavska 340/20

62500 Brno

e-mail: boudny.miroslav@fnbrno.cz

Submitted/Obdrženo: 11. 9. 2019

Accepted/Přijato: 6. 11. 2019

doi: 10.14735/amko202032 


\section{Introduction}

Signal transducer and activator of transcription (STAT) proteins are intracellular transcription factors involved in cellular immunity, proliferation, apoptosis and differentiation. Aberrantly expressed STAT proteins were found to play an important role in cancer promotion [1]. Importantly, constitutive activation of STAT proteins have been found in several leukaemias including acute myeloid leukaemia [2-4], acute promyelocytic leukaemia [5], acute lymphoblastic leukaemia [6], chronic myeloid leukaemia [7] and chronic lymphocytic leukaemia (CLL) $[8,9]$. Importantly, in CLL STAT3 was constitutively activated in all analysed samples regardless of genetic aberrations, disease stage or other factors $[8,10]$. Therefore, it plays a crucial role in CLL. In this review we focus on the role of STAT3 in CLL biology.

\section{STAT3}

STAT3 belongs to the STAT family of signal responsive transcription factors which are kept in an inactive form in the cytoplasm of non-stimulated cells [11]. STAT proteins are cytoplasmic transcription factors that convey signals from cytokine and growth-factor receptors to the nucleus (Fig. 1) [12]. STAT proteins regulate processes that are acquired by tumour cells such as uncontrolled proliferation, resistance to apoptosis, sustained angiogenesis and escape from the immune system $[12,13]$. STAT3 is activated by phosphorylation of tyrosine residues (Y705) or serine residues $(S 727)[8,11]$. STAT3 activation is most commonly mediated by members of the Janus kinase (JAK) family tyrosine kinases. Then it dimerises and translocates to the nucleus, where it binds specific DNA sequences in the promoters of target genes. STAT proteins (especially STAT3 and STAT5) are constitutively activated in a surprisingly large number of cancers [12]. Remarkably, STAT3 activation is required for the survival and proliferation of a number of cancer cells [11]. STAT3 activation in cancer cells is often the result of chronic stimulation by extracellular signals in the tumour microenvironment.

STAT3 is crucial for cell development, which has been evidenced in experi-

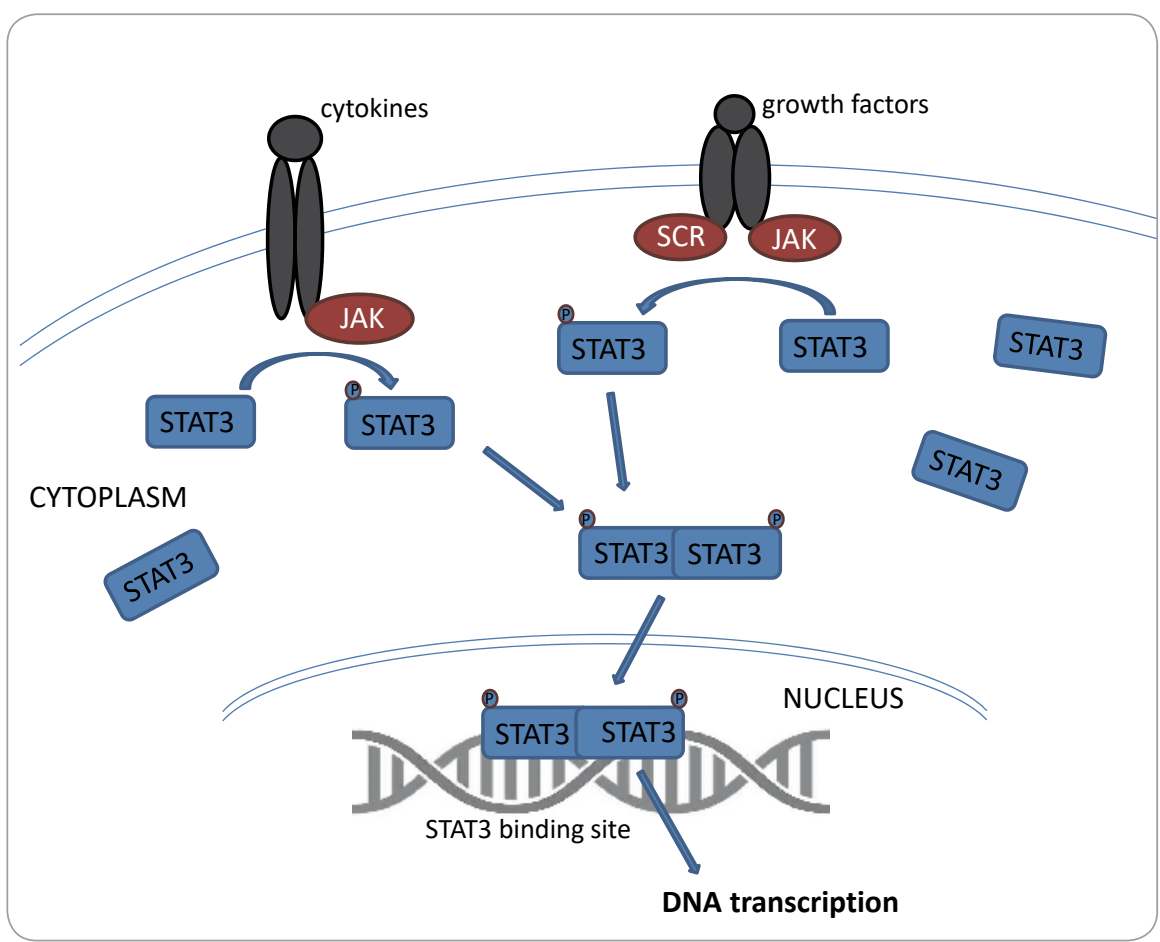

Fig. 1. General STAT3 activation. Inactive non-phosphorylated STAT3 in the cytoplasm is phosphorylated and thus activated by the JAK kinases. It enables dimerization of STAT3. The phosphorylated STAT3 dimers enter the nucleus and bind STAT3 target genes. ments using null (knock out) mice suffering from early embryonic lethality [14]. Constitutive activation of STAT3 has been found to be associated with the initiation and progression of various cancers has been found in several solid tumours and haematologic malignancies; altogether STAT3 is one of the most commonly activated transcription factors in cancer [12].

\section{STAT3 in CLL}

Although CLL is a heterogeneous disease with various genetic aberrations, there are abnormalities in CLL that occur in all patients. One of them is constitutively activated STAT3 protein [8-10]. STAT3 plays a role in promoting tumourigenesis of CLL where it represents a key pathway involved in the growth and survival of CLL cells $[8,9,15,16]$. In CLL, STAT3 messenger RNA (mRNA) expression is significantly higher compared to healthy B-lymphocytes [17-19]. Therefore, the regulation of STAT3 activity is highly dysregulated in CLL cells. STAT3 is involved directly or indirectly in many processes in CLL cells including proliferation, apoptosis, B-cell receptor (BCR) signalling, cytokine secretion, immune checkpoint regulation, microRNA regulation, free fatty acid metabolism and electron transport chain in the mitochondria (Fig. 2).

\section{Constitutive activation of STAT3 in CLL cells}

Constitutive Y705 phosphorylation of STAT3 occurs in several solid tumours and haematologic malignancies [12]. However, it is interesting that in CLL STAT3 is constitutively phosphorylated exclusively on $\mathrm{S727}$ but not on Y705 [8,9]. Conversely, inducible Y705 phosphorylation was transient. In contrast to normal peripheral blood B-lymphocytes, constitutive S727 phosphorylation was detected in all tested samples of CLL, regardless of disease stage or treatment status. Moreover, this phosphorylation is constitutive in CLL cells. Importantly, the S727 phosphorylation also activates STAT3, which translocates to the nucleus, binds to the STAT3-specific DNA binding sites in unstimulated CLL cells and regulates the expression 


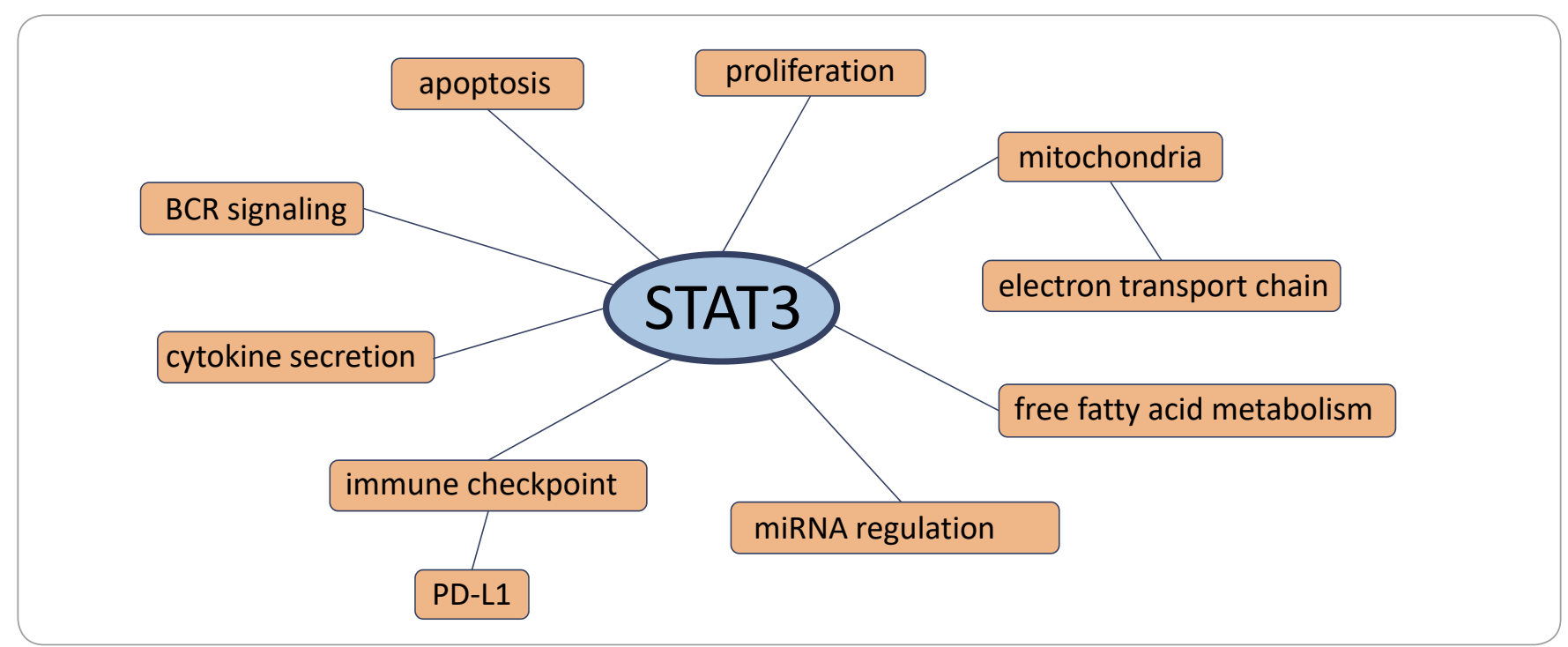

Fig. 2. Processes in which STAT3 is involved in chronic lymphocytic leukemia cells.

STAT - signal transducer and activator of transcription, BCR - B cell receptor, PD-L1 - programmed death-ligand 1, miRNA - microRNA

of STAT3-dependent genes. The elimination of STAT3 using short hairpin RNA ( STAT3 and the STAT3-regulated genes such as $B C L 2$, Pim 1, BCL-XL, Cyclin D1, p21 and $c-M Y C$ in a dose-dependent manner. Besides STAT3, STAT1 was also found to be constitutively activated on S727 residues in CLL cells [9]. In addition, in CLL cells, STAT3 can be activated easily through Y705 phosphorylation because CLL cells reside in the bone marrow, blood and lymph nodes and are thus exposed to various cytokines, chemokines and growth factors and therefore capable of potentiate through this phosphorylation a magnitude of STAT3 activation. Although it is not constitutive in CLL cells, increased pY705 STAT3 levels were described by Myhrvold et al. [20]. In CLL cells, the basal phosphorylation level of proteins involved in B-cell signalling was similar or lower compared to normal B cells, with the exception of pY705 STAT3, which was increased. Constitutive $\mathrm{S} 727$ phosphorylation of STAT3 is biologically significant and probably plays a role in the pathogenesis of CLL because it activates the transcription of pro-survival and pro-proliferative genes. The STAT3 constitutive phosphorylation on $\mathrm{S} 727$ residues is induced by casein kinase 2 , which is required for the phosphorylation together with SD5 and BLNK; together

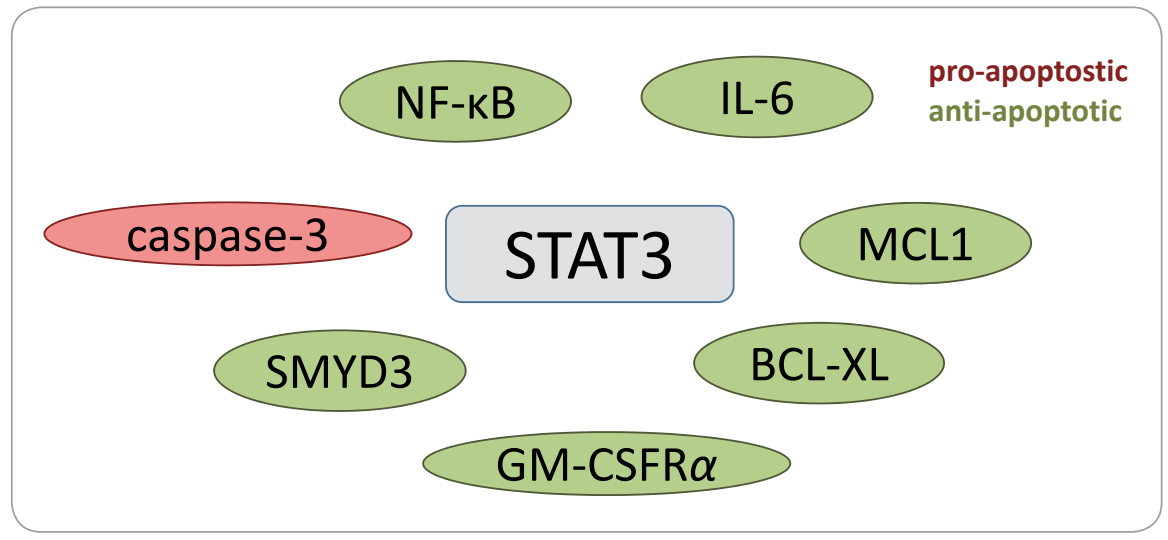

Fig. 3. Directly and indirectly regulated apoptosis by STAT3. Pro-apoptotic proteins are circled in red, anti-apoptotic proteins in green.

STAT - signal transducer and activator of transcription

they create a complex that phosphorylates STAT3 [21]. Moreover, in addition to phosphorylation, STAT3 is constitutively acetylated on K685 in CLL cells [10]. It was detected in all the analysed samples regardless of clinical characteristics, cytogenetic abnormalities or IGHV mutation status. Acetyltransferase p300 was detected at high levels in CLL cells and subsequently it was found that p300 induces constitutive acetylation and activation of STAT3. Acetylated STAT3 increased the transcriptional activity of STAT3 and provided CLL cells with a survival advantage. The acetylation and phosphorylation of STAT3 were found as independent events in CLL cells.

\section{STAT3 in regulating}

\section{CLL cell survival}

Interestingly, it was found that the sensitivity of fresh CLL cells to spontaneous apoptosis is highly variable among different patients and inversely correlates with constitutive activation of STAT3 and NF-kB [22]. Both transcription factors maintain the levels of anti-apoptotic proteins $M C L 1$ and $B C L-X L$ and autocrine IL-6 secretion. The sensitivity of CLL cells to spontaneous apoptosis is thus regulated by STAT3 and NF-kB (Fig. 3).

One reason for increased proliferation in CLL cells is NF- $\mathrm{KB}$ activation. Yang et al. described the mechanism of NF-KB activation through interaction with 
STAT3 [23]. They found that unphosphorylated STAT3 (U-STAT3) binds to NF- $\mathrm{KB}$ dimers in competition with IKB [23]. The $\mathrm{U}-\mathrm{STAT} 3 / \mathrm{NF}-\kappa \mathrm{B}$ complex translocates to the nucleus, binds to the DNA and activates NF- $\mathrm{BB}$-regulated genes. In CLL cells, constitutively activated STAT3 induces STAT3 protein production, and thus CLL cells harbour high levels of U-STAT3. Moreover, Liu et al. confirmed that also in CLL cells U-STAT3 binds to the NF- $\mathrm{KB}$ dimers, forming a complex that activates NF- $\mathrm{BB}$-regulated genes (e.g. VEGF-C, CCL5 and CXCR5) [24]. Further, increased transcription of SMYD3 promotes CLL survival - Lin et al. found that activated STAT3 binds directly to the SMYD3 promoter and enhances SMYD3 transcription [19]. Decreased phosphorylation of STAT3 or SMYD3 knock down inhibited CLL cell growth. Another mechanism which protects CLL cells from apoptosis is STAT3mediated GM-CSFR $\alpha$ ( $\alpha$ subunit of the granulocyte-macrophage colony-stimulating factor receptor) production [25].

On the other hand, STAT3 also regulates the apoptosis of CLL cells [26]. Besides that STAT3 protects CLL cells from apoptosis, at high levels STAT3 can activate pro-apoptotic mechanisms and induce apoptosis in CLL cells. Overexpression of STAT3 upregulated caspase-3 levels and induced apoptosis. STAT3 binds with low affinity to the caspase-3 promoter and at very high levels can activate caspase- 3 expression. This could represent a physiological negative feedback mechanism used in normal cells to counteract uncontrolled proliferation.

\section{Microenvironment activation of STAT3 in CLL cells}

Interestingly, CD5 ${ }^{\text {high }} \mathrm{CXCR} 4^{\text {dim }} \mathrm{CLL}$ cells, which probably recently exited the lymph node, express higher levels of pY705 STAT3 than the CD5 ${ }^{\operatorname{dim}} C X C R 4^{\text {high }}$ CLL cells likely circulating in the peripheral blood [27]. Moreover, the expression of STAT3-target genes was significantly higher in CLL cells isolated from the lymph node than in CLL cells isolated from the blood of the same patient $[27,28]$. Chen et al. found that nurse-like cells could induce Wnt5a/ROR1-dependent activation of NF- $\kappa B$ in CLL cells that in turn elicits au- tocrine IL-6-induced activation of STAT3. Further, it was found that cirmtuzumab, the anti-ROR1 antibody, can inhibit the activation of both STAT3 and NF- $\mathrm{KB}$ in CLL cells.

STAT3 is involved in BCR signalling in CLL cells $[15,16,29]$. BCR stimulation triggers survival signals in CLL cells. BCR stimulation via anti-immunoglobulin $M$ (anti-lgM) antibodies induces transient Y705 phosphorylation and nuclear localisation of PSTAT3 [15]. In contrast, S727 phosphorylation was increased only mildly. BCR activation induces the activation of JAK2, which phosphorylates STAT3 on Y705 residues. Anti-lgM upregulates STAT3-regulated genes CyclinD1, STAT3, p21, c-MYC and BCL2. In addition, Rozovski et al. found that stimulation of the $B C R$ increases the constitutive activation of $N F-\kappa B, N F-\kappa B$ then induces the production of IL-6, which subsequently leads to phosphorylation of STAT3 on Y705 residues [29]. Furthermore, BCR signalling can also activate the second STAT3 phosphorylation; Kondo et al. found that Bruton's tyrosine kinase (BTK) is an upstream activator of pS727 STAT3 in CLL cells [16]. Ibrutinib abrogated IgM/lgG- or CD40L-induced pS727 STAT3 activation. Moreover, BTK knockout significantly reduced the constitutive level of pS727 STAT3. The effect was probably exerted indirectly through the activation of serine kinases.

Further, STAT3 regulates cytokine production in CLL cells. STAT3 was found to regulate the secretion of IL-9 and IL-10 in CLL cells [18,30]. STAT3-mediated translational upregulation of miR-155 and miR-21 promoted IL-9 secretion [18]. Concerning IL-10, the CXCL12-CXCR4STAT3 axis regulates IL-10 production in CLL cells and their ability to suppress T-cell effector function [30].

Moreover, STAT3 directly or indirectly upregulates or downregulates microRNA gene levels in CLL cells including, for example miR-155 involved in tumourigenesis [31]. The levels of 63 microRNAs were downregulated and 9 upregulated after STAT3 shRNA transfection. Li et al. confirmed that STAT3 binds to the miR-155 gene promoter and activates miR-155 expression in CLL cells [32].

\section{STAT3 mediates the response to ibrutinib in CLL cells}

Recently, one of the important effects of ibrutinib, in addition to the inhibition of BTK, is the inhibition of STAT3 signalling, demonstrating the important role of this signalling pathway and the potential for its use in CLL therapy, either through inhibition by ibrutinib or another specific inhibitor [16]. The study showed an interesting link between the STAT3 pathway and regulation of the immune response through programmed death-ligand 1 (PD-L1) expression, which was significantly reduced following treatment with ibrutinib, enhancing the T-cell response in the CLL cells. In the peripheral blood CLL samples treated with ibrutinib, durable downregulation of PD-L1 by 3 months post-treatment was observed. This effect was mediated through the inhibition of constitutively active STAT3 on S727 in the CLL cells. In contrast, chlorambucil therapy had no effect on PD-L1 expression, suggesting a specific effect of ibrutinib treatment. PD-1/PD-L1 receptors play an important role in the anti-tumour immune response, which has recently been used for targeted anti-tumour therapy [33,34]. Moreover, the effect of inhibition of STAT3 and subsequent downregulation of PD-L1 has already been described in lymphoma-derived cell lines [35].

\section{Effect of STAT3 on CLL cell metabolism}

In addition to its classic function as the transcription factor in the nucleus, a pool of pS727 STAT3 molecules has been identified in the mitochondria, where it modulates the activity of the electron transport chain [36]. Importantly, this was also confirmed in CLL cells where the pS727 STAT3 level correlated with prolonged in vivo survival [37]. pS727 STAT3 was detected in the mitochondria and associated with complex I of the respiratory chain. Furthermore, STAT3 activity contributes to the CLL cell but not to healthy $B$ cell resistance to apoptosis in vitro. Mitochondrial pS727 STAT3 overactivity is therefore a part of the antioxidant defence pathway of CLL cells. Thus, mitochondrial pS727 STAT3 appears to be a newly 
Tab. 1. Preclinical and clinical testing of STAT3 inhibition.

\begin{tabular}{l|l|l|l|l|}
\hline Drug & STAT3 targeting & Combination & Model & \multicolumn{1}{l}{ Reference } \\
\hline JSI-124 & directly & single-agent, TRAIL & cell lines, primary cells & Ishdorj et al., 2010 [40] \\
\hline WP1066 and niclosamide & directly & single-agent & primary cells & Myhrvold et al., 2018 [20] \\
\hline WP1066 & directly & single-agent & cell lines, in vivo & Lin et al., 2019 [19] \\
\hline C6-ceramide & indirectly & single-agent, ibrutinib & cell lines, primary cells, ex vivo & Doshi et al., 2017 [48] \\
\hline Pyrimethamine & indirectly & single-agent & clinical trial (NCT01066663) & Brown et al., 2018 [42] \\
\hline Cirmtuzumab & indirectly & single-agent & clinical trial (NCT01066663) & Chen et al., 2019 [27] \\
\hline Ibrutinib & indirectly & single-agent & clinical practice & Kondo et al., 2018 [16]
\end{tabular}

STAT - signal transducer and activator of transcription, TRAIL - tumour necrosis factor-related apoptosis-inducing ligand

identified cell-protective signal involved in CLL cell survival.

Rozovski et al. found that CLL cells, similar to Burkitt's lymphoma cells but unlike normal B-lymphocytes, store lipids in the form of cytoplasmic lipid vacuoles [38]. STAT3 was found to modulate free fatty acid metabolism through aberrant lipoprotein lipase expression in CLL cells. It seems that CLL cells transformed their metabolism to oxidise free fatty acids. Activated STAT3 induces lipoprotein lipase, which catalyses the hydrolysis of triglycerides into free fatty acids. Recently, it was found that STAT3-activated CD36 facilitates fatty acid uptake in CLL cells [39].

\section{Preclinical testing of STAT3 inhibition in CLL}

The inhibition of STAT3 using JSI-124 potently induced apoptosis in B leukaemia cell lines and primary CLL cells [40]. JSI-124 reduced STAT3 S727 phosphorylation.JSI-124 also induced cell cycle arrest prior to apoptosis activation. Moreover, the knockdown of STAT3 induced apoptosis and cell cycle arrest in leukaemia cells. The blocking of STAT3 led to downregulation of an anti-apoptotic protein XIAP. STAT3 inhibitors WP1066 and niclosamide significantly reduced both pY705 STAT3 levels and cell viability [20]. STAT3 inhibition reduced cellular metabolism before cell death was induced. Moreover, WP1066 significantly inhibited tumour growth in vivo [19]. This suggests that STAT3 activation can be a potential target for therapy of CLL (Tab. 1).
In addition, SOCS3, a negative regulator of the JAK/STAT signalling pathway, was found to be a potentially new therapeutic target in CLL using the inhibition of Hsp90 [41]. In this study Hsp90 induced the cell death of CLL cells through upregulation of SOCS3 via the p38 pathway.

\section{Clinical testing of STAT3 inhibition in CLL}

The fact that STAT3 is a promising target for CLL therapy led to the initiation of a clinical trial investigating the efficiency of STAT3 inhibitors. STAT3 inhibitor pyrimethamine was tested in relapsed CLL/SLL (NCT01066663) [42,43]. Pyrimethamine, an anti-microbial drug that is effective in the prevention and treatment of malaria and toxoplasmosis, was found to be a potent STAT3 inhibitor in a screen of a chemical library of drugs already known to be safe in humans $[44,45]$. Pyrimethamine was found to inhibit STAT3 transcriptional function at concentrations known to be safe in patients. The anti-tumour effect of pyrimethamine through STAT3 inhibition was confirmed in murine models of breast cancer [46]. Pyrimethamine inhibited the expression of STAT3-regulated genes in CLL cells ex vivo and decreased the survival of CLL cells [42]. Importantly, peripheral blood mononuclear cells from healthy donors were not affected. A clinical trial was done in CLL patients whose disease progressed despite therapy. There were no dose-limiting toxicities and no significant drug-related toxicities. No objective responses were observed. Half of the patients achieved stable disease for 12 months and two people for 4 and 6 months, respectively. The remaining patients had progressive disease, and all but one patient discontinued therapy for disease progression. The median overall survival was 22 months. Nevertheless, only the highest dose which was applied approached the threshold of $10 \mu \mathrm{M}$ of plasma concentrations, which effectively inhibited STAT3 in vitro. Therefore, it is necessary to increase the dose of pyrimethamine in future studies to determine its efficiency in CLL patients.

Another drug tested in clinical trial (NCT02860676) which indirectly targets STAT3 is cirmtuzumab. Cirmtuzumab, the anti-ROR1 antibody tested in a phase I clinical trial showed the mechanism of its action through downregulating the expression of STAT3 [27]. It downregulated the expression of STAT3 and NF- $\mathrm{KB}$ target genes and reduced the levels of phosphorylated STAT3 and p65 detected in the CLL cells of treated patients.

Therefore, targeting STAT3 may have a high therapeutic potential because normal cells can tolerate a loss of STAT3 function [47].

\section{Summary}

CLL cells harbour constitutively activated STAT3. STAT3 is permanently phosphorylated on $\mathrm{S} 727$ and acetylated on K685 residues in all CLL samples $[8,10]$. The full activation of STAT3 occurs in the lymph nodes, where CLL cells are stimu- 
lated from various stimuli which also activates Y705 of STAT3. For example, BCR signalling is able to increase both types of STAT3 phosphorylation $[15,16]$. Fully activated STAT3 contributes to the increased proliferation and survival of CLL cells in this compartment. It is interesting that, unlike constitutive $\mathrm{S} 727$ phosphorylation detected in all samples, Y705 phosphorylation status varies between samples. Although it is rare, some samples from the peripheral blood also harbour a high level of Y705 phosphorylation indicating a different stimulation of the CLL cells by the microenvironment [15; our unpublished data]. This is in line with the fact that $C D 5^{\text {high }}$ CXCR4 ${ }^{\text {dim }}$ CLL cells (which recently exited the lymph node) express higher levels of pY705 STAT3 than the CD5 ${ }^{\text {dim }}$ CXCR4 $4^{\text {high }}$ CLL cells (circulating in the peripheral blood) [27]. It seems that after exiting the lymph node, CLL cells keep increased anti-apoptotic signalling at least for some time.

This notwithstanding, no STAT3 inhibitor has been approved at the moment for CLL therapy; the effect of STAT3 inhibition can be seen after other drugs such as ibrutinib or cirtuzumab, which indirectly block STAT3 signalling $[16,27]$. Therefore, the blocking of STAT3 contributes to the observed therapeutic effect of ibrutinib in the clinics.

STAT3 plays an important role in CLL biology and pathology because constitutive STAT3 activation on $\mathrm{S} 727$ and $\mathrm{K} 685$ is present in all patient samples regardless of genetic aberration presence $[8,10]$. Therefore, one molecular hallmark of CLL biology is the constitutive phosphorylation and acetylation, and consequently the transcriptional activation of STAT3.

\section{References}

1. Yu H, Pardoll D, Jove R. STATs in cancer inflammation and immunity: a leading role for STAT3. Nat Rev Cancer 2009; 9(11): 798-809. doi: 10.1038/nrc2734.

2. Hayakawa F, Towatari M, lida H et al. Differential constitutive activation between STAT-related proteins and MAP kinase in primary acute myelogenous leukaemia. Br J Haematol 1998; 101(3): 521-528. 10.1046/j.13652141.1998.00720.x

3. Xia Z, Baer MR, Block AW et al. Expression of signal transducers and activators of transcription proteins in acute myeloid leukemia blasts. Cancer Res 1998; 58: 3173-3180 4. Redell MS, Ruiz MJ, Alonzo TA et al. Stat3 signaling in acute myeloid leukemia: ligand-dependent and -independent activation and induction of apoptosis by a novel small-molecule Stat3 inhibitor. Blood 2011; 117(21) 5701-5709. doi: 10.1182/blood-2010-04-280123. 5. Dong S, Chen SJ, Tweardy DJ. Cross-talk between retinoic acid and STAT3 signaling pathways in acute promyelocytic leukemia. Leuk Lymphoma 2003; 44(12): 2023 2029. doi: $10.1080 / 1042819031000116670$

6. Gouilleux-Gruart V, Gouilleux F, Desaint C et al. STATrelated transcription factors are constitutively activated in peripheral blood cells from acute leukemia patients. Blood 1996; 87(5): 1692-1697.

7. Frank DA, Varticovski L. BCR/abl leads to the constitutive activation of Stat proteins, and shares an epitope with tyrosine phosphorylated Stats. Leukemia 1996; 10(11) 1724-1730

8. Hazan-Halevy I, Harris D, Liu Z et al. STAT3 is constitutively phosphorylated on serine 727 residues, binds DNA, and activates transcription in CLL cells. Blood 2010 115(14): 2852-2863. doi: 10.1182/blood-2009-10-230060 9. Frank DA, Mahajan S, Ritz J. B lymphocytes from patients with chronic lymphocytic leukemia contain sig nal transducer and activator of transcription (STAT) and STAT3 constitutively phosphorylated on serine residues. J Clin Invest 1997; 100(12): 3140-3148. do 10.1172/JCl119869.

10. Rozovski U, Harris DM, Li P et al. STAT3 is constitutively acetylated on lysine 685 residues in chronic lymphocytic leukemia cells. Oncotarget 2018; 9(72): 33710-33718. doi: 10.18632/oncotarget.26110.

11. Grivennikov SI, Karin M. Dangerous liaisons: STAT3 and NF- $\mathrm{KB}$ collaboration and crosstalk in cancer. Cytokine Growth Factor Rev 2010; 21(1): 11-19. doi: 10.1016/j.cytogfr.2009.11.005.

12. Yu H, Jove R. The STATs of cancer - new molecular tar gets come of age. Nat Rev Cancer 2004; 4(2): 97-105. doi: 10.1038/nrc1275

13. Hanahan D, Weinberg RA. Hallmarks of cancer: the next generation. Cell 2011; 144(5): 646-674. doi: 10.1016/ j.cell.2011.02.013.

14. Takeda K, Noguchi K, Shi W et al. Targeted disrup tion of the mouse Stat3 gene leads to early embryonic lethality. Proc Natl Acad Sci 1997; 94(8): 3801-3804. doi 10.1073/pnas.94.8.3801

15. Rozovski U, Wu JY, Harris DM et al. Stimulation of the B-cell receptor activates the JAK2/STAT3 signaling pathway in chronic lymphocytic leukemia cells. Blood 2014; 123(24): 3797-3802. doi: 10.1182/blood-2013-10-534073. 16. Kondo K, Shaim H, Thompson PA et al. Ibrutinib modulates the immunosuppressive CLL microenvironment through STAT3-mediated suppression of regulatory B-cell function and inhibition of the PD-1/PD-L1 pathway. Leukemia 2018; 32(4): 960-970. doi: 10.1038/leu.2017. 304

17. Antosz H, Wojciechowska K, Sajewicz J et al. IL-6, IL-10, c-Jun and STAT3 expression in B-CLL. Blood Cells Mo Dis 2015; 54(3): 258-265. doi: 10.1016/j.bcmd.2014.11 006.

18. Chen N, Feng L, Qu H et al. Overexpression of IL-9 induced by STAT3 phosphorylation is mediated by miR-155 and miR-21 in chronic lymphocytic leukemia. Onco Rep 2018: 39(6): 3064-3072 doi: 10.3892/or.2018.6367.

19. Lin F, Wu D, Fang D et al. STAT3-induced SMYD3 transcription enhances chronic lymphocytic leukemia cell growth in vitro and in vivo. Inflamm Res 2019; 68(9): 739749. doi: 10.1007/s00011-019-01257-5.

20. Myhrvold IK, Cremaschi A, Hermansen JU et al. Single cell profiling of phospho-protein levels in chronic lymphocytic leukemia. Oncotarget 2018; 9(10): 9273-9284. doi: 10.18632/oncotarget.23949.

21. Rozovski U, Harris DM, Li P et al. Constitutive phosphorylation of STAT3 by the CK2-BLNK-CD5 complex. Mol Cancer Res 2017; 15(5): 610-618. doi: 10.1158/15417786.MCR-16-0291.

22. Liu FT, Jia L, Wang P et al. STAT3 and NF-kB cooperatively control in vitro spontaneous apoptosis and poor chemo-responsiveness in patients with chronic lymphocytic leukemia. Oncotarget 2016; 7(22): 32031-32045. doi: 10.18632/oncotarget.8672.

23. Yang J, Liao X, Agarwal MK et al. Unphosphorylated STAT3 accumulates in response to IL-6 and activates transcription by binding to NFkappaB. Genes Dev 2007; 21(11): 1396-1408. doi: 10.1101/gad.1553707.

24. Liu Z, Hazan-Halevy I, Harris DM et al. STAT-3 activates NF-kappaB in chronic lymphocytic leukemia cells. Mol Cancer Res 2011; 9(4): 507-515. doi: 10.1158/1541-7786. MCR-10-0559.

25. Li P, Harris D, Liu Z et al. STAT3-activated GM-CSFR $\alpha$ translocates to the nucleus and protects CLL cells from apoptosis. Mol Cancer Res 2014; 12(9): 1267-1282. doi: 10.1158/1541-7786.MCR-13-0652-T.

26. Rozovski U, Harris DM, Li P et al. At high levels, constitutively activated STAT3 induces apoptosis of chronic lymphocytic leukemia cells. J Immunol 2016; 196(10): 4400-4409 doi: 10.4049/jimmunol.1402108.

27. Chen $Y, C$ Chen L, Yu J et al. Cirmtuzumab blocks Wnt5a/ROR1-stimulation of NF-kB to repress autocrine STAT3-activation in chronic lymphocytic leukemia. Blood 2019; 134(13): 1084-1094. doi: 10.1182/blood.2019001366

28. Herishanu Y, Pérez-Galán P, Liu D et al. The lymph node microenvironment promotes B-cell receptor signaling, NF-kappaB activation, and tumor proliferation in chronic lymphocytic leukemia. Blood 2011; 117(2): 563-574. doi: 10.1182/blood-2010-05-284984.

29. Rozovski U, Harris DM, Li P et al. Activation of the Bcell receptor successively activates NF- $\mathrm{KB}$ and STAT3 in chronic lymphocytic leukemia cells. Int J Cancer 2017; 141(10): 2076-2081. doi: 10.1002/ijc.30892.

30. Shaim H, Estrov Z, Harris D et al. The CXCR4-STAT3IL-10 pathway controls the immunoregulatory function of chronic lymphocytic leukemia and is modulated by lenalidomide. Front Immunol 2018; 8: 1773. doi: 10.3389/fimmu.2017.01773

31. Rozovski U, Calin GA, Setoyama T et al. Signal transducer and activator of transcription (STAT)-3 regulates microRNA gene expression in chronic lymphocytic leukemia cells. Mol Cancer 2013; 12: 50. doi: 10.1186/14764598-12-50.

32. Li P, Grgurevic S, Liu Z et al. Signal transducer and activator of transcription-3 induces microRNA-155 expression in chronic lymphocytic leukemia. PLoS ONE 2013; 8(6): e64678. doi: 10.1371/journal.pone.0064678. 33. Xu-Monette ZY, Zhou J, Young KH. PD-1 expression and clinical PD-1 blockade in B-cell lymphomas. Blood 2018; 131(1): 68-83. doi: 10.1182/blood-2017-07-740993. 34. Darvin P, Toor SM, Sasidharan Nair V et al. Immune checkpoint inhibitors: recent progress and potential biomarkers. Exp Mol Med 2018; 50(12): 165. doi: 10.1038/s12276-018-0191-1.

35. Ma C, Horlad H, Pan C et al. Stat3 inhibitor abrogates the expression of PD-1 ligands on lymphoma cell lines. J Clin Exp Hematop 2017; 57(1): 21-25. doi: 10.3960/jslrt.17006.

36. Wegrzyn J, Potla R, Chwae YJ et al. Function of mitochondrial Stat3 in cellular respiration. Science 2009; 323(5915): 793-797. doi: 10.1126/science.1164551.

37. Capron C, Jondeau K, Casetti L et al. Viability and stress protection of chronic lymphoid leukemia cells involves overactivation of mitochondrial phosphoSTAT3Ser727. Cell Death Dis 2014; 5: e1451. doi: 10.1038/cddis.2014. 393

38. Rozovski U, Grgurevic S, Bueso-Ramos C et al. Aberrant LPL expression, driven by STAT3, mediates free fatty acid metabolism in CLL cells. Mol Cancer Res 2015; 13(5): 944953. doi: 10.1158/1541-7786.MCR-14-0412.

39. Rozovski U, Harris DM, Li P et al. STAT3-activated CD36 facilitates fatty acid uptake in chronic lymphocytic leukemia cells. Oncotarget 2018; 9(30): 21268-21280. doi: 10.18632/oncotarget.25066 
40. Ishdorj G, Johnston JB, Gibson SB. Inhibition of constitutive activation of STAT3 by curcurbitacin-I (JSI-124) sensitized human B-leukemia cells to apoptosis. Mol Cancer Ther 2010 9(12): 3302-3314. doi: 10.1158/1535-7163.MCT-10-0550. 41. Chen TL, Gupta N, Lehman A et al. Hsp90 inhibition increases SOCS3 transcript and regulates migration and cell death in chronic lymphocytic leukemia. Oncotarget 2016; 7(19): 28684-28696. doi: 10.18632/oncotarget.8760.

42. Brown JR, Walker SR, Heppler LN et al. A clinical trial of the STAT3 inhibitor pyrimethamine in chronic lymphocytic leukemia. Blood 2018; 132: 1855-1855.

43. clinicaltrials.gov. Pyrimethamine for the treatment of relapsed chronic lymphocytic leukemia/small lympho- cytic lymphoma. [online]. Available from: https://clinicaltrials.gov/ct2/show/NCT01066663.

44. Takakura A, Nelson EA, Haque $N$ et al. Pyrimethamine inhibits adult polycystic kidney disease by mod ulating STAT signaling pathways. Hum Mol Genet 2011; 20(21): 4143-4154. doi: 10.1093/hmg/dd 338.

45. Legorreta-Herrera M, Retana-Ugalde R, Ventura-Gallegos $J L$ et al. Pyrimethamine induces oxidative stress in Plasmodium yoelii 17XL-infected mice: a novel immunomodulatory mechanism of action for an old antimalarial drug? Exp Parasitol 2010; 126(3): 381-388. doi: 10.1016/j.exppara.2010.02.013.
46. Khan MW, Saadalla A, Ewida AH et al. The STAT3 inhibitor pyrimethamine displays anti-cancer and immune stimulatory effects in murine models of breast cancer. Cancer Immunol Immunother 2018; 67(1): 13-23. doi: 10.1007/s00262-017-2057-0.

47. Inghirami G, Chiarle R, Simmons WJ et al. New and old functions of STAT3: a pivitol target for individualized treatment of cancer. Cell Cycle 2005; 4(9): 1131-1133. doi: 10.4161/cc.4.9.1985

48. Doshi UA, Shaw J, Fox TE et al. STAT3 mediates C6-ceramide-induced cell death in chronic lymphocytic leukemia. Signal Transduct Target Ther 2017; 2: 17051. doi: 10.1038/sigtrans.2017.51. 